\title{
GENDER EQUALITY: THE NEED FOR ENFORCEMENT OF LEGISLATION INNIGERIA
}

\author{
Mary Agbo \\ Department of Political Science, Federal University, Dutsinma Katsinastate, Nigeria
}

\begin{abstract}
This paper studies the struggle for gender equality in Nigeria and findings indicated that despite the ratification by the Nigerian Government on the Convention on the Elimination of All Forms of Discrimination against Women (CEDAW) in 1985 and the Protocol to the African Charter on Human and Peoples' Rights on the Rights of Women in Africa in 2005; the lives of Nigerian women are yet to attain a commensurate level of improvement, as Nigerian women rank lower than men in all indices of development in the country. The paper also observes that the rights of women enshrined in the Nigerian Constitution are consistent with the ideals of humanism. But unfortunately, the rights and ideals have remained paper tigers, mere theoretical postulations without any practical bearing on the lives and conditions of the Nigerian women. Other findings revealed that despite some positive actions taken by the Nigerian government in promoting gender equality as showcased by adoption of a gender policy in 2007 and establishment of women development centers in all states in Nigeria amongst other credible initiatives; there were salient failures as discovered in the current patriarchal structure of the Nigerian society; and failure of the national assembly to pass the gender and equal opportunity bill. The paper recommends series of concrete strategies that should be adopted to acculturate gender equality in Nigeria, which should be anchored on legislation of laws, both at federal and state level that premise on promoting gender equality.
\end{abstract}

Keywords: women, legislature, equality, gender, law, Nigeria

\section{INTRODUCTION}

Nigeria ratified the Convention on the Elimination of All Forms of Discrimination against Women (CEDAW) in 1985, and the Protocol to the African Charter on Human and Peoples' Rights on the Rights of Women in Africa in 2005(Africa union,2010). The protocol was adopted on 11 July 2003 by the AU to strengthen the promotion and protection of women's rights in Africa. By virtue of the Protocol, Nigerian women are guaranteed the right to dignity; the right to life, integrity and security of their persons; freedom from harmful practices which negatively affect the human rights of women; equal rights in marriage; the right to equal protection and benefit of the law; the right to participate in political and decision making process; the right to education and training; equal opportunity in work and career advancement; the right to health, including sexual and reproductive rights; the right to a positive cultural context; widow's rights; the right to equitable share in inheritance; and a right of remedy to any woman whose right or freedom has been violated (Omoyemen, 2010). Furthermore, 1999 Constitution of Nigeria prohibits discrimination on the grounds of sex, religion and political beliefs

From the aforementioned, the opposite is the reality in the life of Nigerian women. For the fact that Nigeria is a federal republic, each state has the authority to draft its own legislation and the combination of federation and a tripartite system of civil, customary and religious law makes it very difficult to harmonize legislation and remove discriminatory measures. Coupled with the patriarchal nature of Nigerian society gender inequality has been established, maintained and grounded in the country.

But then why did the Nigerian government endorse these international human rights concerning elimination of discrimination against women? Is this a mere formality to show that the country too belongs 
to the international communities that has seen the evil of inequality suffered by women? Could this be connected to the reason for the rejection of Gender and Equality Opportunity Bill by Nigeria National Assembly? The paper exposes the gender inequality as despicable, dysfunctional and therefore, detestable thing that Nigerian women have experienced in the patriarchal society. The paper concluded that the best thing that will happen to Nigeria people is the legalization of Gender and Equal Opportunity Bill.

\section{Meaning of Equality}

Equality means everyone is accorded the same rights in the society in the absent of privileges and special rights. Despite difference in physical, psychological, and capacities of individual, all human beings are to be treated equally is known as natural equality (Ghai, 2015). All are to be considered worthy of enjoying all human rights and freedoms. The equal right for all is in line with the fact that all men are born equal and free, therefore they have to be treated and rewarded equally. These rights will allow the individuals to develop their talents to the highest level that they can attain without interference. Ghai had argued that equality does not mean absolute equality. The natural and absolute equality of all cannot be realized and acceptable in the real world. For in reality men are neither equal in respect of their physical features nor in their mental abilities. Some people are stronger than others, while some are more intelligent and capable than others, therefore they can never be treated equally. As such equality of treatment and rewards cannot be guaranteed. Rewards essentially depend upon the actual capabilities and work done.

Ghai further asserted that equality which should mean absence of all unnatural and unjust inequalities do not exist in the society. But what exist are two types of inequalities, natural inequalities and man-made inequalities. The former means natural differences among individual persons. These have to be accepted by all. The latter known as man-made inequalities are those formed by some socioeconomic conditions and discriminations. These occur due to the operation of the social system such as in patriarchal society. This is where inequality women suffer is instituted. The discrimination and inequality against women in the society is a man made, accepted by all include the women.
Conley on his on part has postulated that equality can occur by opportunity as "the idea that everyone has an equal chance to achieve wealth, social prestige, and power because the rules of the game, so to speak, are the same for everyone"(Conley, 2013). This concept can be applied to society by saying that no one has a head start. This means that, for any social equality issue dealing with wealth, social prestige, power, or any of that sort, the equality of opportunity standard can defend the idea that everyone had the same start. It views society almost as a game and any of the differences in equality are due to luck and ability of the player. Conley compared this to the game of monopoly to describe society. He claims that "Monopoly follows the rules of equality of opportunity" by explaining that everyone had an equal chance when starting the game and any differences were a result of the luck of the dice roll and the skill of the player to make choices to benefit their wealth. His argument does not tally with that of Ghai. The game of opportunity would have be the wonderful theory of equality if it can be applied in real world. In the real world people do not have equal start, especially women.

\section{Equality and Women}

Gender equality entails the concept that all human beings, both men and women, are equal and free to develop their personal abilities and make choices without the limitations set by stereotypes, rigid gender roles and prejudices. This means that the different behavior, aspirations and needs of women and men are considered and valued equally. It does not mean that women and men have to become the same, but that their rights, responsibilities and opportunities will not depend on whether they are born male or female. This concept may be taken to primarily refer to the full equality of men and women to enjoy the complete range of political, economic, civil, social and cultural rights, with no one being denied access to these rights, or deprived of them, because of their sex(Wikipedia,)

In relation with this gender equality is gender equity. Gender equity on the other hand is the process of allocating resources, programs and decision-making fairly to both males and females. It does not necessarily mean making the same programs and facilities available to both males and females. It 
requires that girls and women be provided with programs that meet their needs, interests and experiences (CAAWS). It has narrower and strongly economic implications. But in many cases this is not how many societies are structured. History reveals that economic and political power enables those groups and individuals who hold it to maintain their domination and exploitation of others, promote inequality and discrimination ( appadorai, A. 2001). This could elucidate the reason why women are be subjected to inequality because they are in a disadvantage position.

The discriminations and inequalities are societal structures that are instituted against women. Only a few organized societies where women's rights are recognized and respected, apply the principle of gender equality and equity. Gender inequality index data indicator of 2010available for 138 countries indicated that the world average score on the Gender Inequality Index was 0.56 , reflecting a percentage loss in achievement across the three dimensions (of reproductive health, empowerment and labor market participation) due to gender inequality of 56 percent. Regional patterns reveal that reproductive health is the largest contributor to gender inequality around the world - women in Sub-Saharan Africa, with a massive 99 percent loss, suffer the most in this dimension (wiki Gender index 2010). From the data presented above Nigeria is amongst the Sub-Saharan Africa countries where inequality is very high.

\section{Gender inequality in Nigeria}

Gender inequality in Nigeria is expressed in the following dimensions:

Inequality in marriage: the forms of marriages recognized and officially instituted in Nigeria are Customary, Christian, and Islamic and Court or Registry marriages. Upon marriage, all of a woman's property became her husband. Her personal property (jewelry, clothes, cash, etc.) become his absolutely; he could do what he wants with it. She is authorized to use her husband's property, but cannot dispose of it as her own.( Imasogie, 2010).

The situation of women marriage under customary marriage is worst with regard to property rights. As Nigerian cultures vary so also the treatment of women in customary marriage varies. For instance the Orokam people in the Ogbadibo Local Government of Benue State, a woman married under the customary law belong to the husband in totalityall she owes and herself are the property of her husband. Her properties and her wealth can be disposed of by her husband if he is in need of money without her consent. She cannot take a legal and monetary discussion without the husband authorization. Upon divorce, all she earns in the duration of the marriage are seized by the man; even the dowry paid on her head is returned to him. Many divorce women are denied custody and access to their children, nothing is left for her and she goes out of the marriage empty handed. This is the major reason why divorce is rare in this community. The women prefer to endure the marriage whatever condition they find themselves. If she is widowed, her life is miserable, she is left in the mercy of male relations of her late husband who will deal with her as they please. She is force into marriage with one of them, on rejection of this marriage she may be sent away in dejection.

Among those under Islamic law, child marriage is still prevalent. Many of these girls are married out without their consent. According to Baobab Women's Human Rights is not considered, the rights to choice one's partner were not granted to these girls. Girls are often married between the ages of 9-14.

The law gave men power over women in marriage under the doctrine of coverture gave men legal rights while depriving women of theirs rights; at the same time, the law does little or nothing to protect women from abuses by their husbands. Coverture is described [Blackstone, 1765] as making husband and wife legally one person-the husband but legal existence of the women is suspended during the marriage because her legality is incorporated into that of the husband, under whose protection and cover she does everything. The practical effects of coverture is that a woman could not make contracts or take legal actions in her own name, could not bring cases against her husband because legally, that would be bringing case against herself. She did not have rights over her children or even her own body, and could not control her own property. A man who raped another man's wife or committed adultery with her would be offending against the husband's property rights 
(Imasogie, 2010).This applies only to court or registry marriage.

Assaults and violence against Women: violence against women has existed time immemorial. This violence comes in different shapes and forms. It could be physical, mental or psychological violence. These included cases of women's rights violation such murder, rape, widow abuse, and physical assaults. Unfortunately, it is only extreme cases that violent against women which results in death or permanent disability that gets the media attention and the appropriate authorities. Similarly, in Nigeria, laws to protect women from violence are pathetic. For example, marital rape is generally not recognized as an offence in any system of law in Nigeria, even when the wife is wounded in the course of forced sexual intercourse. Formal mechanisms to seek redress in cases of domestic violence or rape, through police investigation followed by a court proceeding, are often ineffective (salaam, 2003).Moreover, the victims of domestic violence hardly report to the law enforcement agencies. Under the discriminatory laws, it has been pointed out that Section 55(1) (d) of the Penal Code for the 19 states of northern Nigeria permits a man to beat his wife for insubordination and the purpose of correcting her, provided that the result does not amount to the infliction of grievous hurt.

Inequality in Labor Matter: women are mostly discriminated in the area of employment. Issues of inequality confronting women in the economic sector are enormous. This is why women are predominant in the micro-economic sector due to lack of technological and managerial skills. Unequal payment met to women even where they do the same job as men, women are cultural stereotype discrimination against. This is mostly finding in unskilled labor job that may involve male and female. Even if they performed the same work as men, women are pay less because of the belief that men are physically stronger than the women. ( Imasogie, 2010).

In some public organization, women are highly discriminated against. For instance, discrimination is found in the Police Act Regulation 118 provides that a woman desirous of joining the police force must be unmarried. Under Regulation 124 of the law, a woman police officer wanting to get married must first apply in writing to the Commissioner of Police of the Police Command in which she is serving, requesting for permission to marry, and must submit the name, address and occupation of the man she intends to marry. Approval will be granted for marriage if the proposed husband is of good character and the women officer has served in the force for a period of not less than 3 years. It should be noted that the same provision does not apply to male police men. Also under Regulation 127 of the Police Act, the employment of a woman police is not secured, as she is automatically discharged from the force upon getting pregnant. She can only be re-enlisted with the approval of the Inspector General of Police. This practice explains why the Police Force is predominantly filled with men. In the same vein, the Air Force Act is also discriminatory against female.

Discriminatory law against women: The Section 39(3) of the constitution allows men to confer citizenship on their foreign spouses but does not allow the reverse in case of Nigerian women married to foreign men.

Discrimination in politics and education: women face restrictions or barriers in politics in Nigeria, a country where only seven of the 109 senators are women. Mrs. Aisha Al-Hassan, the Minister of Women Affairs observed that in Nigeria, women represented 49 per cent of the population, yet they occupied less than six per cent of parliamentary seats at the national level. In the educational sector in spite of Nigeria long exposure to Western education, more than 50 percent of Nigerian women are still said to be illiterates due to preference given to the education of boys.

Obnoxious code legislations against women: this include denial of women right to the custody of their children after divorce, violation of women's right to inheritance of their husband's/father's properties but permits the son or the brother of a deceased person to inherit his property to the exclusion of his female children. Under this code the denial of women's right to exist as a separate legal entity, and others. 


\section{The Need for Enforcement of Legislation of Gender and Equality of Opportunity Bill in Nigeria}

The Gender and Equal Opportunity Bill has the following objective:

- $\quad$ To give effect to the chapter II and IV of the Constitution of Federal Republic of Nigeria;

- The international Covenants on Human Rights which affirms the principle of nondiscrimination and proclaims that all humans are born free and in dignity and rights, and that everyone is entitled to all the rights set out without distinction of any kind including distinction base on sex; and

- The domestication of certain provision of the Convention of Elimination of All Forms of Discrimination against Women and the protocol to African Charter on the Rights of Women in Africa and National Gender Policy.

The bill is to ensure promotion of equality, full development and advancement of all persons; adoption of temporary special measures to eliminate discrimination - in political and public life, in the field of education, employment and health; elimination of discrimination on the ground of marital status and on socio-economic ground. It is also to grantee the rights to choice of indigene-ship and identity, in matters relating to marriage and family relation and of persons in rural communities. Furthermore, it is to ensure the provisions relating to marriage and matrimonial causes and to offence and sentencing including damages and compensations. And lastly, the establishment of gender and equality opportunity commission (http://www.aacoalition, 2011)

Nigerian lawmakers on Tuesday, March 15, 2016, vote against the passage of this important bill that will affect the life of every Nigerian. Those who opposed the bill cited cultural and religious views of Nigerians. A male colleague argued in support of those who oppose the bill opined that the passing of the bill will work against the people from the core northern region of country due to their culture and religion which restrict women in so many ways. For instance, a national job which may require equal number of men and women to fill their quarter as federal character demands, the core north will be disadvantaged because they will not have enough women to fill their quarter. He asserted that gender parity will not be supported because it will not favor the northern cause. Another reason for non-passage of the bill might be the adoption of the bill would a threat and a challenge to the existing patriarchal institution. Any woman on the street knows that Nigeria men see women equality as a threat to their liberty. The National Assembly has men as the majority who cherishes their liberty and the patriarchal institution of inequality of women and men and would not want women to have share of it. So they quickly threw out the bill on its second reading.

When the bill was thrown out, many people cried in the social media

The bill is important because everyone knows one woman at least who has experienced injustice, discrimination at the office, child marriage, or has been cheated out of her inheritance. At least I know one, I know more than one. Many women across Nigeria daily go through these injustices that make life miserable and I have shared in their pain and if possible, I would help be the solution and I believe that is what Senator Biodun Olujimi is fighting for. What every woman should be fighting for and what the men who love them should be fighting for because we can't make it work without the support of all, men and women.(Abike Dabiri-Erewa 2016)

The bill if passed sought to end questionable and unpleasant stereotype practices that motivate discrimination based on gender and ensure liberty and equality. Liberty and equality are two most valuable rights of the people which no tradition and constitution should work against. These constitute two basic pillars of democracy that spurall men and women to contribute to the development of their society through participation in the formation and 
implementation of policies that affect their life (Ghai, 2010). It would have brought a significant leap in the advancement of women in Nigeria in conformity to UN Convention and the Protocol of African Charter of rights of African Women and other related instruments on the rights and development of women.

\section{CONCLUSION AND RECOMMENDATION}

This paper has successfully demonstrated that in equality of gender in Nigerian is expressed-in marriage, in labor matter, assaults and violence against women, discriminatory law against women, discrimination in politics and education and obnoxious code legislations against women. Nigerian women are being marginalized as the result of inequality in political and decision-making process, employment, economic and opportunities. The study revealed that inequality has done a prodigious harm to the development of women who form half of the population and impaired their contribution to the economy of this great country. We conclude that the Nigerian women to get out of this awful situation the Gender and Equality opportunity must be passed into law.

Therefore the following strategies should be adopted to acculturate gender equality in Nigeria:

The equality clause of the Nigerian Constitution must be amended to give better protection to Nigerian women.

Modification of socio- cultural practices- agency of government, both public and private institutions and other social entity including educational institutions shall have the responsibility to modify the social and cultural patterns of conduct of men and women, with a view of achieving the elimination of gender stereotyping, prejudices, and customary and all other practices which are based on the idea of the inferiority or the superiority of either of the sexes, or the roles for men and women.

Women have immense potential for self-development in all aspects of life, when given the opportunity. It is their lack of opportunity and exposure that impedes their self- realization. Interaction among women in an environment free from family distractions will help them to open up their minds, which will lead to development thinking. This will engender the women's awareness of their human rights and obligations as citizens of Nigeria and to fight for their rights.

A key strategy in promoting women's empowerment and gender equality has to be adopted for constructive action that will correct the age-long gender imbalance in Nigerian societies. The positive Action strategies have to become political instruments for meeting the needs of the women who have been unethically shut out of mainstream development and societal system.

Men are invited to take up the gender equality seriously. "Gender equality is your issue, too", says Emma Watson. She further stressed that men are being imprison by gender stereotypes."But I can see that they are, and that when they are free, things will change for women as a natural consequence," emphasized Emma. She argued that if men don't have to be aggressive in order to being accepted as men, women won't be compelled to be submissive; and if men don't have to control, women won't have to be controlled. Nigerian men should borrow a leave from this girl's advice.

\section{REFERENCE}

Abike, D.( 2016)Guardian.ng/opinion.com/why-thegender-and- equality-bill is importantappadorai, A. (2001) the substance of politics: New Delhi: BAOBAB for Women's Human. Rights www.awlprojectorg/.../30Spet07_WhyNigerianWome nFailinElections

CEDAW (Committee on the Elimination of Discrimination against Women) (1997), Consideration of Reports Submitted by States Parties Under Article 18 of the Convention on the Elimination of All Forms of Discrimination against Women: Nigeria, Combined Second and Third Periodic Reports of States Parties, CEDAW/C/NGA/2-3, CEDAW, New York, NY.

Conley, D. (2013). You May Ask Yourself (3rd ed.). New York: W. W. Norton \& Company CONSTITUTION OF THEFEDERAL REPUBLIC OF NIGERIA1999 Chapter IVFundamental Rights Nigerian Constitution, 1999

Ghai, K.K (2015), Equality: Meaning, Features and Types of Equality, Copyright (C) 2015 YourArticleLibrary.com, All rights reserved. Sitemap Imasogie, M.O. (2010) 'gender sensitivity and discrimination against women under statute and common law in Nigeria', International Journal of Sustainable Development 02: 05 (2010) 11-18 
Omoyemen, O (2010) 'AssessingWomen's Rights in Nigeria' foreign Policy in focus a project of the Institute for Policy Studies. Originally published in Pambazuka
Watson, E. (2014) 'Watson's moving speech about gender equality and the he for she" HeForSheSpeech at the United Nations http://www.genderindex.org/country/nigeria 